\title{
Morphometric analysis of river subwatersheds using geographic information system and principal component analysis, northeast of Algeria
}

\author{
Kamel KHANCHOUL ${ }^{1 *}$, Bachir SAAIDIA ${ }^{2}$ \\ ${ }^{1}$ Soils and Sustainable Development Laboratory, Badji Mokhtar University-Annaba, Algeria \\ ${ }^{2}$ Water Resources and Sustainable Development Laboratory, Badji Mokhtar University-Annaba, Algeria \\ Received 2 November 2017; Revised 25 November 2017; Accepted 12 December 2017 \\ *Correspondence to: Kamel KHANCHOUL, e-mail: kam.khanchoul@gmail.com
}

\begin{abstract}
In the present paper an attempt is made to study the morphometric characteristics of five watersheds which are part of Seybouse and Coastal basin of Constantine located in northeast of Algeria. The study focuses on evaluating the effect of morphometric parameters on land degradation. The Geographical Information Systems which represent efficient tools in determination of drainage basin morphometric properties and principal component analysis are applied to ten geomorphic parameters on twenty subwatersheds, to group the parameters under different components based on significant correlations. Some morphometric parameters are computed and analyzed such as basin area, drainage density, stream frequency, form factor, orographic coefficient, hypsometric integral, and lithology index, basin slope, average overland flow distance, basin relief ratio. Outcomes of the matrix of correlation and principal component analysis of ten geomorphic parameters clearly depict that fifty percent of the variables are strongly correlated with the components like basin area, drainage density, stream frequency, orographic coefficient and relief ratio. It has been found that Guis sub-basin, three sub-basins of the Saf Saf watershed and all the sub-basins of the Mellah watershed are subjected to high land degradation, thus, creating an urgent need for applying soil and water conservation measures.
\end{abstract}

KEYWORDS

Subwatershed; GIS; morphometric analysis; correlation matrix; principal component analysis; Algeria 


\section{Introduction}

Morphometry is the measurement and mathematical analysis of various characteristics of a drainage basin that can be quantitatively described (Pidwirny, 2006). Morphometric descriptors, which include classes of linear, areal, and relief aspects, represent relatively simple approaches to describe basin processes and to compare basin characteristics (Mesa, 2006) and enable an enhanced understanding of the geological and geomorphic history of a drainage basin (Strahler, 1964).

The quantitative analysis of morphometric parameters is of great importance in river basin evaluation, watershed prioritization for soil and water conservation, and natural resources management. Geology, relief, and climate are the key determinants of running water ecosystems functioning at the basin scale (Frissel et al., 1986). In addition, the hydrological response of a river basin can be interrelated with the physiographic characteristics of the drainage basin, such as size, shape, slope, drainage density and size, and length of the streams, etc. (Chorley, 1969; Gregory and Walling, 1973).

A number of studies have utilized the technique of Geographical Information System and digital elevation models for assessing various terrain and morphometric parameters of the drainage basins as they provide a flexible environment and a powerful tool for statistical, comparative and analytical analyses for better understanding (Vijith et al., 2006; Fahran et al., 2017). In the present paper many morphometric data have been extracted using GIS environment (ArcGIS) from SRTM data.

The statistical method for reducing a large number of interrelated variables into a smaller number of dominant variables is called principal components analysis (Wuttichaikitcharoen et al., 2014). Synder (1962), Wong (1979) and Sharma et al. (2013a) have clearly shown the use of multiple regression analysis for establishment of hydrological prediction equations using morphometric parameters. Mishra and Satyanarayana (1988) have applied principal component analysis on ten geomorphic parameters at Damodar Valley catchment and grouped the nine parameters into three significant components, like drainage, slope and shape. Singh et al. (2009) also applied principal component analysis to thirteen geomorphic parameters collected for sixteen subwatersheds of Chambel catchment of Rajasthan. Sharma et al., 2013b; Sharma et al., 2014a; Bilewu et al., 2015; Hajji et al. 2015; Fahran et al., 2017; Meshram and Sharma, 2017; Sunil and Mukhopadhyay, 2015 have used PCA for their works on geomorphic parameters for hydrological modeling, for redundancy of morphometric parameters and identifying the dominant descriptors which contribute to explain the watershed erosion.

The main objective of the study is to determine and analyse some morphometric characteristics and relate them to land degradation variability in various subhumid areas located in the eastern part of Algeria. The present study depicts the process to evaluate the various morphometric parameters by using prioritizition of subwatersheds and multivariate statistical approach to the Seybouse basin (Bouhamdane, Ressoul, Mellah watersheds) and Coastal basins of Constantine (Kebir West and Saf Saf watersheds).

\section{Study area}

Watersheds of northern Algeria constitute a Mediterranean domain where different forms of erosion are highly distributed. Most Algerian wadis are developed in areas of young and rugged terrain with usually a very complex geological structure. In the Tell, the hillslopes formed in marly formations of Cretaceous or Tertiary clay layers favor the spatial extension of gullies and mass wastings (Kouriet al., 1997). The establishment of the hydrographic network of the basins of the Algerian Oriental Tell is made from a topography that existed in the Pliocene. At the end of the Pliocene, tectonic movements gave the Tell its mountainous volume (Marre, 1992). These movements are at the origin of the resumption of downcutting of the rivers which could incise deep valleys and gorges. 
The northeastern part of Algeria's climate is a humid temperate climate. The Algerian basins are dominated by two climate regimes: coastal temperate climate and Tellian Atlas climate. This study is based on data from five watersheds representing different physico-climatic regions of northern Algeria (Figure 1). Selected basins have areas that extend from 103 to $1130 \mathrm{~km}^{2}$ and receive average rainfall ranging between $550 \mathrm{~mm}$ and 900 $\mathrm{mm}$. Considering the hydrologic conditions, it appears that the Mellah, Saf Saf and Ressoul watersheds behave as a highly efficient runoffgenerating unit, with annual runoff coefficients ranging between $22 \%$ and $27 \%$. The stream flow response to rainfall becomes less pronounced when the runoff efficiency of Kebir West and Bouhamdane wadis is examined, where annual runoff coefficients are $12 \%$ and $20 \%$ respectively. The mean annual water discharges range between $0.93 \mathrm{~m}^{3} / \mathrm{s}$ in Ressoul Wadi to $3.25 \mathrm{~m}^{3} / \mathrm{s}$ in Mellah Wadi.

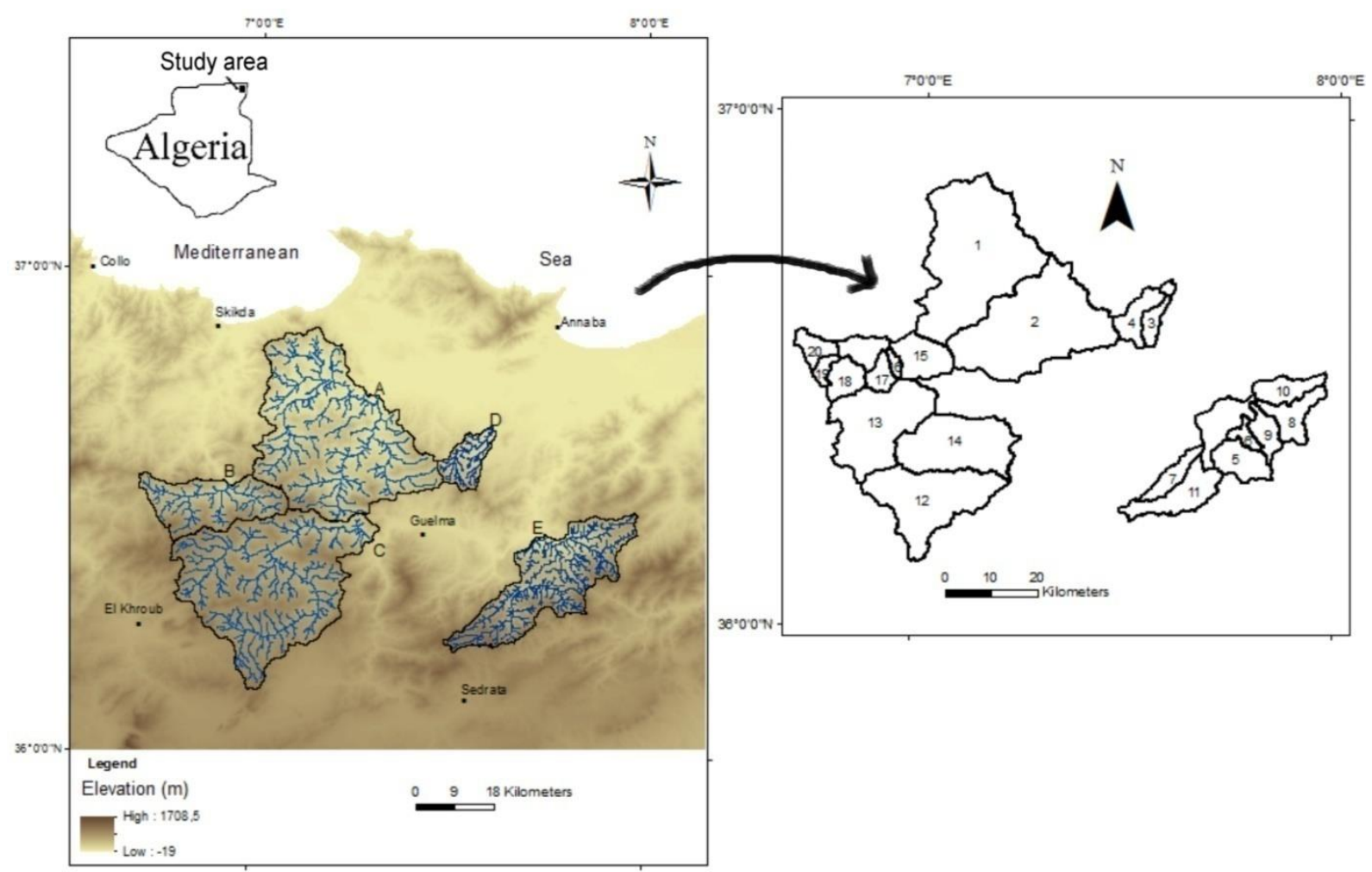

Figure 1 Location map of the study subwatersheds. Watersheds: A: KebirWest ;B: SafSaf;C: Bouhamdane; D: Ressoul; E: Mellah. Subwatersheds : 1: Emchekel; 2: el Hammam; 3: Guis; 4: Bouala; 5: Rirane; 6: Cheham; 7: Hammam; 8: Meza; 9: Aouassia; 10: Bouredine; 11: R'biba; 12: Zenati; 13: Sabath; 14: Bouhamdane; 15: Khemakhem; 16: M'taRhumel; 17: Khorfane; 18: Rararef; 19: Beni Brahim; 20: Bou Adjeb

The basins of the Constantine Coastal region and Seybouse are characterized by a considerable distribution of resistant rocks such as Oligocene sandstone and moderately to weak rocks such as Creataceousmarly limestone, triasic formations, marl and clay of different ages. Aggressive flows were able to scar on erodible rocks by carrying huge amounts of suspended sediment in the wadis of Mellah, Saf Saf and Kebir West.
The evolution of the Algerian Oriental Tell is marked first of all by a rapid transgression. At the end of the Miocene, there is a gradual emergence of Tell. Due to the neotectonics (characterized by faults and thrust sheets at the end of the Miocene and during the Pliocene and Quaternary) the Algerian Oriental Tell acquired its mountainous volume (Marre, 1992). Also, the mountain character of the Tell is due to its humid and cool climate on the 
summits and steep hillslopes. The proximity of the sea is at the origin of very active downcutting of the valleys. There is an evolution equivalent to that described in northern Sicily (Hugonie, 1979) and in Calabria (Gueremy, 1977). It is from the existing topography in the Pliocene that the drainage network is realized (Dresch, 1950). The tectonic movements are the origin of the resumption of downcutting of streams that have developed deep valleys and gorges.

After the establishment of the thrust sheets, the Saf Saf River settled on an old topography constructed by detrital materials of the Upper Oligocene. It was from there the river would be superimposed (inadapted to the geologic structure). It is at the end of the Miocene that there is a resumption of erosion on Saf Saf River which has downcutted its current valley through the Numidian chain (sandstone, clay, flysch) and conglomerates.

The morphostructural study of the Neritic limestones in the North Guelmian Tell (eg. Bouhamdane, Mellah and Ressoul watersheds) has permitted to highlight the important role of tectonic accidents such as faults in the formation of reliefs in the region; it is post-mio-pliocene tectonics (late Tertiary and Quaternary). These disturbances accentuated the reliefs such as Djebels Debagh, Taya, considered young reliefs and accelerated the establishment of the hydrographic network which crossed softer rocks. Finally, the mountains that surround the large Azzaba Basin, a principal part of the Kebir West watershed, to the north, west, and south consist of Numidian sandstones and the bottom is covered by quaternary sediments. This is a hollow area in which came to settle the Numidian clays due to thrust sheet dynamics. The tectonic accidents gave birth to the different reliefs and erosion has been able to release deep valleys by a river network thought to have been surimposed during the end of the Tertiary.

Using the French classification of soils (Duchaufour, 1983), most of the watersheds have extended areas of poorly developed soils (lithosols and regosols). Soils developed on sandstone and limestone, with slopes exceeding 12\%, are constantly rejuvenated and have a less differentiated soil profile (Bneder 1980 and 1995).
Besides the poorly developed soils in the Saf Saf, Mellah and Kebir West watersheds, calcareous soils (calcisols), and deep brown soils are developed on slopes less than $15 \%$ steep. The vertisols are frequent in the Kebir West and Bouhamdane watersheds. They are deep and rich in clay, usually montmorillonite which causes the soil to shrink and crack upon drying and to swell and produce surface runoff when wet (Khanchoul et al., 2007 and 2008).

The natural vegetation that protects the soil is disturbed by man. The cultivated areas are the most vegetation cover of the study areas. In the Saf Saf and Bouhamdane watersheds $65 \%$ and $57 \%$ of their basin areas are cultivated with wheat and barley. The lands of Kebir West and Ressoul watersheds, and especially Mellah basin, are less used for farming, occupying $40 \%$ and $17 \%$. Dense forests (mainly Oak cork) and shrubland (Oleo-lentiscus and Erica europa) are less developed in the Saf Saf and Bouhamdane watersheds, with $26 \%$ and $12 \%$ of their basin areas respectively. The rest of the basins are better covered with forest and grassland, exceeding $30 \%$.

\section{Materials and methods}

For delineation of the Bouhamdane, Resoul, Mellah, Kebir West and SafSafwatersheds and preparation of drainage map the information regarding the topography is needed. In this study, the Digital Elevation Model (DEM)is used, which is tagged information file format (TIFF) format with $30 \mathrm{~m}$ ground resolution. Further, the developed DEM is processed to generate or delineate the watershed and drainage network (Fig. 1), using the hydrologytool of Spatial Analyst module of ArcGIS 10 (Meshram and Sharma, 2017). Further, twenty subwatershed boundaries are also determined from the five principal watersheds: Kebir West (two subwatersheds), Saf Saf (six subwatersheds), Ressoul (two subwatersheds), Mellah (seven subwatersheds) and Bouhamdane (three subwatersheds).

The order is given to each stream by following a stream ordering technique of Strahler (1964). The term "stream order" is a measure of the position of a stream in the hierarchy of tributaries where the 1storder streams are those, which have no 
tributaries. The 2 nd order streams are those where two 1st order channels join, when two 2nd order channels join, a segment of 3rd order is formed. When two 3rd order segments join, a 4th order channel is formed and so on.

Morphometric analysis is carried out for the watersheds and their subwatersheds. The parameters computed in the present study using geological maps (1:50,000 scale) and GIS technique, within the attribute tables to compute necessary morphometric quantities, include stream order, stream length, basin area, drainage density, stream frequency, orographic coefficient, maximum and minimum elevation, mean elevation and hypsometric integral (Table 1). The input parameter for the present study such as lithology index is obtained from digitized coverage of geological maps in GIS environment. Supplementary geomorphic parameters such as form factor, average basin slope, average overland flow distance and basin relief ratio are added to find out the qualified significance of each variable. The different morphometric parameters for the watersheds and subwatersheds are determined as shown in Table 2.

Table 1 Methods of calculating morphometric parameters

\begin{tabular}{|c|c|c|}
\hline Geomorphic parameters & Formula & Source \\
\hline Basin area $(A)$ & Calculate geometry in attribute table & DEM and Arcgis \\
\hline Meanelevation (Hmean) & $\begin{array}{l}\text { Raster calculator expression: } \\
\text { Con("DEM">1500, "DEM") }\end{array}$ & DEM and Arcgis \\
\hline Drainage density (Dd) & $\begin{array}{l}\mathrm{Dd}=\mathrm{Lu} / \mathrm{A} \\
\mathrm{Lu}: \text { total stream lengths of all orders using Arcgis }\end{array}$ & Horton (1945) \\
\hline Stream frequency (F1) & $\begin{array}{l}\mathrm{F} 1=\mathrm{N} 1 / \mathrm{A} \\
\mathrm{N} 1: \text { number of all } 1 \text { st order streams using Arcgis }\end{array}$ & Horton (1945) \\
\hline Form factor (C) & $\begin{array}{l}\mathrm{C}=\mathrm{A} / \mathrm{Lb}^{2} \\
\mathrm{Lb}: \text { basin length }\end{array}$ & Schumm (1956) \\
\hline Orographic coefficient (OC) & $\begin{array}{l}\text { OC }=\text { Hmean } \times \operatorname{tang} \alpha \\
\operatorname{tang} \alpha=\frac{\text { Hmean }-H \min }{A} \\
\text { Hmean: mean elevation; Hmin: minimum elevation }\end{array}$ & Fournier (1960) \\
\hline Hypsometricintegral (HI) & $\begin{array}{l}\qquad \mathrm{HI}=\frac{\text { Hmean }-H \min }{H \max -H \min } \times 100 \\
\text { Hmean: mean elevation; Hmin: minimum elevation; } \\
\text { Hmax. maximum elevation }\end{array}$ & Pike et Wilson (1971) \\
\hline Lithologic index (IL) & $\begin{array}{l}\text { Rock erodible area/basin area } \\
\text { Erodible area (marl, clay, marly limestone) }\end{array}$ & Demmak (1982) \\
\hline Average basin slope (BS) & $\begin{array}{l}\text { Average slope of the triangles or cells comprising this } \\
\text { basin. A triangle or cell's slope is computed as the } \\
\text { change in elevation divided by the change in XY or plan } \\
\text { distance. }\end{array}$ & $\begin{array}{l}\text { DEM and Watershed } \\
\text { Modeling System } \\
\text { program (WMS) }\end{array}$ \\
\hline $\begin{array}{l}\text { Average overland flow } \\
\text { distance } \\
\text { (OFD) }\end{array}$ & $\begin{array}{l}\text { - Averaging the overland distance traveled from the } \\
\text { centroid of each triangle to the nearest stream. } \\
-L=A / 2 W\end{array}$ & DEM and WMS \\
\hline & A: basin area; W: channel length & Horton (1945) \\
\hline Basin relief ratio $(\mathbf{R h})$ & $\begin{array}{l}\mathrm{Rh}=\mathrm{R} / \mathrm{L} \\
\mathrm{R}: \text { total relief (max elevation - min elevation); L: } \\
\text { maximum basin length }\end{array}$ & Schumm (1956) \\
\hline
\end{tabular}


Table 2 Morphometric characteristics of the watersheds and subwatersheds of the study area A: basin area; Dd: drainage density; F1: stream frequency; HI: hypsometric integral; OC: orographic coefficient; IL: lithologic index; C: form factor; BS: average basin slope; OFD: average overland flow distance; Rh: basin relief ratio

\begin{tabular}{|c|c|c|c|c|c|c|c|c|c|c|c|}
\hline & Code & $\begin{array}{c}\mathrm{A} \\
\left(\mathrm{km}^{2}\right) \\
\end{array}$ & $\begin{array}{c}\mathrm{Dd} \\
\left(\mathrm{km}^{-1}\right)\end{array}$ & $\begin{array}{c}\mathrm{F} 1 \\
\left(\mathrm{~km}^{-2}\right) \\
\end{array}$ & $\begin{array}{c}\mathrm{HI} \\
(\%) \\
\end{array}$ & OC & $\begin{array}{c}\text { IL } \\
(\%) \\
\end{array}$ & C & $\begin{array}{c}\text { BS } \\
(\%)\end{array}$ & $\begin{array}{l}\text { OFD } \\
(\mathrm{km}) \\
\end{array}$ & $\mathrm{Rh}$ \\
\hline \multicolumn{12}{|l|}{ Watersheds } \\
\hline Kebir West & - & 1130 & 2.60 & 5.28 & 21.17 & 62.24 & 32.51 & 1.14 & 15.33 & 0.70 & 0.035 \\
\hline SafSaf & - & 322 & 3.60 & 5.90 & 41.62 & 823.00 & 16.10 & 1.27 & 19.08 & 0.75 & 0.045 \\
\hline Bouhamdane & - & 1105 & 2.61 & 4.30 & 49.50 & 350.41 & 23.89 & 1.76 & 11.99 & 0.74 & 0.022 \\
\hline Ressoul & - & 103 & 3.41 & 6.84 & 29.06 & 780.43 & 34.21 & 1.25 & 12.35 & 0.68 & 0.050 \\
\hline Mellah & - & 550 & 4.53 & 6.07 & 42.93 & 590.69 & 20.27 & 1.45 & 18.55 & 0.77 & 0.037 \\
\hline \multicolumn{12}{|l|}{ Subwatersheds } \\
\hline Emchekel & Eck & 641.60 & 2.96 & 5.71 & 24.91 & 0.92 & 26.71 & 1.40 & 13.73 & 0.70 & 0.017 \\
\hline el Hammam & Ehm & 485.00 & 2.75 & 5.89 & 29.37 & 2.72 & 40.07 & 1.20 & 11.24 & 0.70 & 0.029 \\
\hline Guis & Gui & 64.65 & 3.58 & 8.00 & 30.51 & 13.02 & 31.23 & 1.49 & 13.10 & 0.66 & 0.048 \\
\hline Bouala & Bal & 33.45 & 3.00 & 5.06 & 25.79 & 20.02 & 43.31 & 1.45 & 12.17 & 0.68 & 0.073 \\
\hline Rirane & Rrn & 79.03 & 3.98 & 7.81 & 53.19 & 50.61 & 26.92 & 1.22 & 18.81 & 0.83 & 0.060 \\
\hline Cheham & Chm & 29.81 & 4.90 & 6.07 & 44.44 & 103.05 & 60.88 & 1.67 & 14.27 & 0.69 & 0.078 \\
\hline Hammam & $\mathrm{Hmm}$ & 54.46 & 4.30 & 7.38 & 44.00 & 59.93 & 18.32 & 1.54 & 21.78 & 0.68 & 0.051 \\
\hline Meza & Mez & 77.03 & 4.72 & 4.87 & 55.38 & 34.78 & 21.45 & 1.64 & 16.55 & 0.84 & 0.057 \\
\hline Aouassia & Aos & 48.11 & 4.48 & 3.62 & 56.38 & 74.91 & 13.01 & 1.31 & 15.99 & 0.88 & 0.075 \\
\hline Bouredine & Brn & 64.40 & 3.78 & 3.79 & 49.01 & 26.91 & 28.54 & 1.43 & 15.98 & 0.87 & 0.038 \\
\hline R'biba & $\mathrm{Rbb}$ & 128.66 & 2.74 & 6.19 & 54.62 & 36.76 & 11.32 & 1.55 & 21.97 & 0.68 & 0.037 \\
\hline Zenati & Zen & 575.17 & 2.42 & 3.68 & 46.34 & 4.04 & 36.18 & 1.47 & 10.51 & 0.70 & 0.013 \\
\hline Sabath & Sab & 314.18 & 2.09 & 3.50 & 44.8 & 9.42 & 5.15 & 1.61 & 11.36 & 0.71 & 0.025 \\
\hline Bouhamdane & Bhm & 215.65 & 3.84 & 7.08 & 39.00 & 10.79 & 55.98 & 1.29 & 16.85 & 0.88 & 0.030 \\
\hline Khemakhem & $\mathrm{Kmk}$ & 99.47 & 3.26 & 5.36 & 41.47 & 26.49 & 26.03 & 1.37 & 20.86 & 0.71 & 0.054 \\
\hline M'ta Rhumel & $\mathrm{Rml}$ & 13.78 & 3.81 & 8.85 & 43.50 & 157.07 & 23.44 & 1.43 & 21.07 & 0.79 & 0.134 \\
\hline Khorfane & Kfn & 35.24 & 3.29 & 5.05 & 50.72 & 86.50 & 12.57 & 1.19 & 19.39 & 0.82 & 0.094 \\
\hline Rararef & Rra & 58.80 & 3.06 & 3.93 & 53.31 & 59.68 & 1.54 & 1.34 & 19.01 & 0.76 & 0.069 \\
\hline Beni Brahim & $\mathrm{Bbr}$ & 68.19 & 4.84 & 7.86 & 31.93 & 22.30 & 15.69 & 1.48 & 19.70 & 0.65 & 0.086 \\
\hline Bou Adjeb & Baj & 46.52 & 3.36 & 6.47 & 37.97 & 32.82 & 15.65 & 1.25 & 14.42 & 0.70 & 0.041 \\
\hline
\end{tabular}

The statistical methods are applied to validate data and to obtain further precise results. The various morphometric parameters are studied for their inter-relationship which helps to depict the nature of the subwatersheds. Thus, astatistical analysis of multivariate types is used to manage the information provided by the used parameters. Multivariate analysis is a useful technique for identifying common patterns in data distribution, leading to a reduction of the initial dimension of data sets and facilitating their interpretation (Castellano et al., 2007).

Statistical analyses are carried out by the statistical software (STATISTICA version 8). The interpretation of the correlation between the variables will be done using the correlation matrix. Then, for the grouping of geomorphic parameters principal component analysis will be used on the geomorphic parameters for twenty subwatersheds. 
Principal component analysis (PCA) is applied for all geomorphic parameters to summarize the information contained in a large array of numbers, to identify patterns, to better understand the tangible relationship between the variables, and thus to reduce data in order to highlight the essential elements related to the erosion process. Factor analysis is a classic form of multivariate analysis, widely used in the social sciences since the 1960s. In this analysis we have used the STATISTICA software, which is designed to be used as simply as possible.

\section{Results and discussion}

\subsection{Geomorphic parameters analysis}

\subsubsection{Drainage density}

Drainage density is of great interest because it is directly controlled by the interaction of geology and climate (Ritter, 1984). The drainage density has been related to a number of climatic indices (Gardiner and Park, 1978). Gregory and Gardiner (1975) have examined variation of drainage density in relation to both world climatic zones and precipitation within one zone. In general, surfaces with a resistant substrate or those characterized by high infiltration capacities have spaced streams and therefore low drainage densities. As surface resistance or permeability decreases, runoff becomes more important, resulting in tighter rivers and drainage density tends to become higher. Added to that the abundance of precipitation, which is responsible for the perenniality or the intermittence of the rivers.

The drainage density values obtained from subbasins are between 2.09 and $4.90 \mathrm{~km}^{-1}$. The subwatersheds of Mellah and Saf Saf show the highest values, with averages equal to $4.13 \mathrm{~km}^{-1}$ and 3.60 $\mathrm{km}^{-1}$, respectively. This is also evident in those basins which reach the highest values (Table 2). Much of the other sub-basins belonging to the Kebir West and Bouhamdane show better drainage, especially in fractured sandstones and plains, with an average of $2.86 \mathrm{~km}^{-1}$ and $2.78 \mathrm{~km}^{-1}$.

\subsubsection{Stream frequency}

This is obviously a parameter that accounts for a density-in-number effect, certainly comparable to the density-in-length effect that Dd represents. The frequency values of the talwegs (F1) vary between 3.00 and 8.85. The calculated averages show that the sub-basins of Ressoul and that of SafSaf have values greater than 6.00 , while the sub-basins of Mellah and Kébir West have mean values of 5.68 and 5.80. The permutation of the Ressoul and Mellah wadis on the basis of the values of the drainage density and the frequency of the talwegs reveal the existence of a larger number of talwegs, often shorter (lower orders), which evolve on erodible surfaces composed of clay-sandstone and marl-limestone in the Ressoul watershed. The streams of Mellah Wadi, on the other hand, tend to develop more by lateral erosion, hence its increase in sinuosity and length. The lowest values of the frequency of the talwegs are observed in the Zenati and Sabath sub-basins which form part of the Bouhamdane watershed.

Without taking into account the used averages, we find that the wadis of Mellah, Saf Saf and Ressoul generally have the highest drainage density values and the frequency of the talwegs (Table 2).

\subsubsection{Relief relations}

This group indicates the vertical dimensions of the basin; it includes gradient and elevation factors. The mean elevation of the sub-basins has not been systematically analyzed in the various discussions of the relief since it is more a characteristic of state whose influence is mainly felt at the level of the climate (rainfall, temperature). It is better represented by the orographic coefficient and hypsometry.

The orographic coefficient reflects the energy of a morphometry favorable or unfavorable to erosion. It is therefore an indicator of the intensity of the processes of erosion operating on the slopes of which it measures the general steepness of the basin. This coefficient is probably similar to the relief ratio proposed by Melton (1957). Most of the values of the orographic coefficient of the 
subwatersheds range from 157 to 2.72 . Taking into account the calculated averages of this coefficient, we note that Saf Saf Wadi $(\overline{\mathrm{CO}}=64)$ and Mellah Wadi $(\overline{\mathrm{CO}}=55)$ have the highest values, which implies a high energy of landform favorable to erosion. But if the coefficient is recalculated by the formula in Table 1 for the five basins, we note that the wadis of Saf Saf and Ressoul come first, followed by Mellah Wadi (Table 2). It is usually the sections of the subwatershed not considered in the calculations that change the classification of the basins.

Subjected to geomorphological processes, the shape of a basin changes over time. According to Davis's classical analysis (1899, 1905), hillslopes, gradient of streams and drainage density increase rapidly during the youth stage to reach their maximum at the beginning of maturity, before they decrease slowly (Schumm, 1956). Davis suggests that the basins are developed after an abrupt tectonic uplift followed by soil erosion. Hack (1960) has provided an enthusiastically embraced alternative to Davisian thought that has established the concept of dynamic equilibrium landforms as a fundamental time-independent geomorphic model. In addition, Scheidegger (1987) has contradicted the Davisian hypothesis by asserting that the uprising is a continuous process and that, through the history of the basin, there is a tendency towards equilibrium between the two opposing forces, tectonics and erosion. Thus, the youth stage would correspond to a strong activity of these two antagonistic processes. The stage of maturity corresponds to an average activity and therefore to dynamic equilibrium.

The analysis of the different stages of the evolution of the relief is determined from the hypsometric curve, data collected from the altimetric maps and the hypsometric integral $(\mathrm{HI})$. Hypsometric analysis (area-altitude analysis) has been used to differentiate between erosional landforms at different stages during their evolution (Strahler, 1952; Schumm, 1956; Pike and Wilson, 1971). Thus, it has been possible to calculate the current mass of the relief which is not yet consumed by erosion. A hypsometric curve, having a concaveconvex shape with a hypsometric integral between
35 and $60 \%$, shows a stage of maturity where the equilibrium state of the basin development is reached. A strongly concave curve and a hypsometric integral of less than $35 \%$ give an endmaturity stage predominantly dominated by hills and ridges. This is the monadnock phase (Strahler, 1952). The values of the integral hypsometric range between $24.91 \%$ and $56.38 \%$ of which $25 \%$ of the values are less than $35 \%$.

The sub-basins of the Kebir West, Ressoul Wadi, the sub-basin of the Beni Brahim Wadi (belonging to Saf Saf watershed) correspond to an advanced stage of maturity, which leads to a hypsometrically concave curve, more elongated downwards. These sub-basins have reached the monadnock phase where they are characterized by a predominance of scattered hills, generally medium to low, with often rounded summits. This is clearly visible in these subbasins where the proportion of low-lying areas resting on less resistant rocks increases progressively at the expense of a higher topography formed of resistant rocks. According to Strahler, this situation is transitory and when it is completed, it will result in the restructuring of a curve giving a normal steady-state form (Rafael, 1990). This is possible only when the hard rocks are exposed, leaving a certain contrast between the topography of the erodible parts and the more resistant ones of the basin. This result is also apparent in the basins of Kebir West and Ressoul (Table 2).

Among the sub-basins which are in a state of dynamic equilibrium (mid-maturity stage), we note that Aouassia Wadi and Bouhamdane Wadi present the most extreme hypsometric integral values, with respectively $56.38 \%$ and $37.35 \%$ (Table 2). As a result, Aouassia Wadi presents a less concave curve whose "sub-maturity" condition can be explained by insufficient time to reach full mid-maturity. The relief, developed in conglomerates and fractured sandstones, seems to be accentuated and the drainage density is quite high.

Overall, the Bouhamdane, Saf Saf and Mellah watersheds show a mid-maturity stage where more than $50 \%$ of the initial relief is consumed by erosion. These are basins in equilibrium; therefore, there is an attainment of a regular state related to the processes of erosion and transportation within 
the fluvial system and its contributing slopes. In this stage, a system of channel slopes and valley-wall slopes has been developed which is most efficiently adapted to the reduction of the landmass with available erosionial forces, balanced against the resistive forces of cohesion, maintained by the bedrock, soil, and plant cover (Strahler, 1952).

The relief ratio measures the overall steepness of a drainage basin and it is an indicator of intensity of erosion processes operating on the slope of the basin. Relief ratio normally increases with decreasing drainage area and size of a given drainage basin (Gottschalk, 1964). The values of relief ratio in the study watersheds range between 0.022 and 0.050 . This is a dimensionless heightlength ratio and allows comparison of the relative relief of any basin regardless of difference in scale or topography. The values of the relief ratio in the study subwatersheds range between 0.023 and 0.122 (Table 2). It has been observed that areas with low to moderate relief and slope are characterized by moderate value of relief ratios. Low value of relief ratios are mainly due to the resistant basement rocks of the basin and low degree of slope.

\subsection{Multivariate analysis of the physical parameters}

Some physical parameters have been used in the PCA analysis for the sub-basins of the Seybouse and the coastal basins of Constantine in order to determine the affinities between the sub-basins and to deduce accordingly the most characteristic parameters with regard to erosion.

The PCA method has been applied to 20 cases (sub-basins) and 10geomorphic variables that could contribute to erosion. The major selected variables are sub-basin area (A), drainage density (Dd), frequency of talwegs (F1), hypsometric integral (HI), orographic coefficient (OC), lithological index (IL). Four additional variables, sub-basin shape parameter (C), basin slope (BS), average overland flow (OFD) and basin relief ratio (Rh) are considered as extended variables.

\subsubsection{Principal component analysis of major dataset}

PCA is used iteratively to provide a number of outputs, all of which require interpretation leading to an inherent tradeoff between simplicity and precision. The first output provided by a PCA is a correlation matrix (Table 3). A Spearman correlation matrix is used because it is sensitive to outliers than the more commonly used Pearson correlation matrix. Table 3 demonstrates moderate negative correlations between sub-basin area and drainage density, orographic coefficient. The negative correlation between basin area and drainage density and stream frequency suggests that there should be a positive correlation between basin area and total stream length, total number of streams. The computed coefficient of correlation between basin area and total stream length is equal to 0.98 . The four basin characteristics that change in response to the changes taking place in basin area, as a result of drainage re-organization following the removal of the remnants of the pre-existing planation surface, are total stream length, drainage density, stream frequency and the relief ratio that will be treated in the following section (Mather and Doornkamp, 1980). By considering the mean values of these parameters for the subwatersheds, the slight decrease in drainage density (from 3.60 to $\left.3.43 \mathrm{~km}^{-1}\right)$, during maturity $(35 \%<=\mathrm{HI}<60 \%)$ to late maturity-old $(\mathrm{HI}<35 \%)$ stage, shows that in the ratio total stream length/basin area, the area increases more than total stream length, leading to a decrease of the drainage density value. Meanwhile, the simple linear relationship between basin size and mean elevation fails to explain this association, which is not significant $(r=-0.33)$.

Much weaker positive correlations are apparent between drainage density and orographic coefficient and between hypsometric integral and orograohic coefficient. In addition, a weaker negative correlation is observed between hypsometric integral and lithologic index. It is the combination of these variable correlations that PCA is introduced to capture mathematically.

The correlations shown in Table 3 are translated into PCs by computing eigenvalues where the greater the eigenvalues, the greater the proportion of variability is explained by the component (Table 4). 
Table 3 Matrix of correlations between geomorphic variables

\begin{tabular}{ccccccc}
\hline Parameters & A & Dd & F1 & HI & OC & IL \\
\hline A & 1.00 & & & & & \\
Dd & $\mathbf{- 0 . 5 7}$ & 1.00 & & & & \\
F1 & -0.26 & 0.38 & 1.00 & & & \\
HI & -0.36 & 0.19 & -0.34 & 1.00 & & \\
OC & $\mathbf{- 0 . 5 7}$ & 0.43 & 0.27 & 0.43 & 1.00 & \\
IL & 0.17 & 0.19 & 0.22 & -0.41 & -0.10 & 1.00 \\
\hline
\end{tabular}

Table 4 Eigenvalues of correlation matrix and related statistics

\begin{tabular}{ccccc}
\hline & Eigenvalue & $\begin{array}{c}\text { \% Total } \\
\text { variance }\end{array}$ & $\begin{array}{c}\text { Cumulative } \\
\text { Eigenvalue }\end{array}$ & $\begin{array}{c}\text { Cumulative } \\
\%\end{array}$ \\
\hline PC1 & 2.40 & 40.08 & 2.40 & 40.08 \\
PC2 & 1.71 & 28.49 & 4.11 & 68.57 \\
PC3 & 0.76 & 12.61 & 4.87 & 81.18 \\
PC4 & 0.52 & 8.66 & 5.39 & 89.85 \\
PC5 & 0.36 & 5.93 & 5.75 & 95.78 \\
PC6 & 0.25 & 4.22 & 6.00 & 100.00 \\
\hline
\end{tabular}

Table 5 Factor coordinates of the variables, based on correlations

\begin{tabular}{|c|c|c|c|c|c|c|}
\hline $\begin{array}{l}\text { Parameter } \\
\mathrm{s}\end{array}$ & $\begin{array}{c}\text { Factor } \\
1 \\
\end{array}$ & $\begin{array}{c}\text { Facto } \\
\text { r } 2 \\
\end{array}$ & $\begin{array}{c}\text { Factor } \\
3 \\
\end{array}$ & $\begin{array}{c}\text { Facto } \\
\text { r } 4 \\
\end{array}$ & $\begin{array}{c}\text { Factor } \\
5 \\
\end{array}$ & $\begin{array}{c}\text { Factor } \\
6 \\
\end{array}$ \\
\hline$A$ & 0.86 & 0.02 & 0.08 & -0.26 & 0.42 & 0.13 \\
\hline Dd & -0.75 & 0.36 & 0.28 & 0.35 & 0.25 & 0.21 \\
\hline F1 & -0.37 & 0.73 & -0.48 & -0.09 & 0.21 & -0.22 \\
\hline $\mathrm{HI}$ & -0.53 & -0.71 & 0.28 & -0.08 & 0.24 & -0.28 \\
\hline$O C$ & -0.82 & -0.04 & -0.03 & -0.53 & -0.06 & 0.21 \\
\hline $\mathrm{IL}$ & 0.15 & 0.74 & 0.60 & -0.19 & -0.12 & -0.15 \\
\hline
\end{tabular}

The correlation between the six variables (Table 3) and between the variables and principal components (Table 5) are represented graphically in the correlation circle provided in Figure 2. The correlation circle is a graphical tool for determining the variables that contribute the most to the formation of the principal component analysis. The angle of the vectors relative to the two PC axes reflects the degree of association between the variables and the PCs. Similarly, the angle of each vector relative to other vectors reflects the degree of correlation between the variables (US Department of Energy, 2012).

The circle of correlations of the variables shows that the factors $1-2$ represent almost $69 \%$ of inertia. Drainage density (Dd) and orographic coefficient (OC) are negatively well represented on PC1 based on the small angle between the vectors. The subbasin area (A) is opposed to the later two variables. Stream frequency (F1) and lithologic index (IL) are positively correlated with the second component, PC2 (the vertical axis). On this axis, the hypsometric integral $(\mathrm{HI})$ is negatively correlated with PC2. The position of the vectors for $\mathrm{F} 1$, IL at about less than $45^{\circ}$ angles to PC2 axis, indicates that these constituents are more or less well represented in the PCA as are the other variables such as Dd and OC.

The tendency to link the parameters of drainage density and relief to sub-basin area on factor 1 seems to be able to express the active morphology of the field under various lithological formations (Fig. 2). A high value of the orographic coefficient and drainage density characterizes the sub-basins with small areas. The sub-basin area increases to high values when the proportion of the sub-basin to the low relief increases and the intensity of erosion decreases.

In order to interpret this relationship on the basis of our data, it is imperative to specify that the analyzed sub-basins are in a stage of maturity, which implies that they are distinguished by more aerated reliefs with well developed alluvial plains or micro-plains. Thus, sub-basins with fairly high to high reliefs are characterized by high drainage densities because the steepness of the slopes contributes enormously to the intense gullying. However, erosion continues by the development of the hydrographic network and contributes to the widening of the valley and the reduction of the relief. The expansion of the upstream parts of the drainage system results in the consumption of most undissected surfaces and consequently leads to the elongation of the basin (Miller et al., 1990). With the reduction of the relief, the intensity of the gullying decreases progressively because the slope of the basin becomes less favorable to the high flows. In 
addition, the existence of the plains promotes the infiltration of runoff into the soil and the development of the meandering system.

The circle of correlations, connected to factors $1-3$ with almost $53 \%$ of inertia, shows that axis 3 is mainly controlled by the lithologic index with a positive correlation. The position of its vector at small angle to PC3 indicates that it is as fairly well represented in the PCA and the frequency stream variable is less correlated because the position of the vectors are at about $45^{\circ}$ angles to PC1 and PC3.
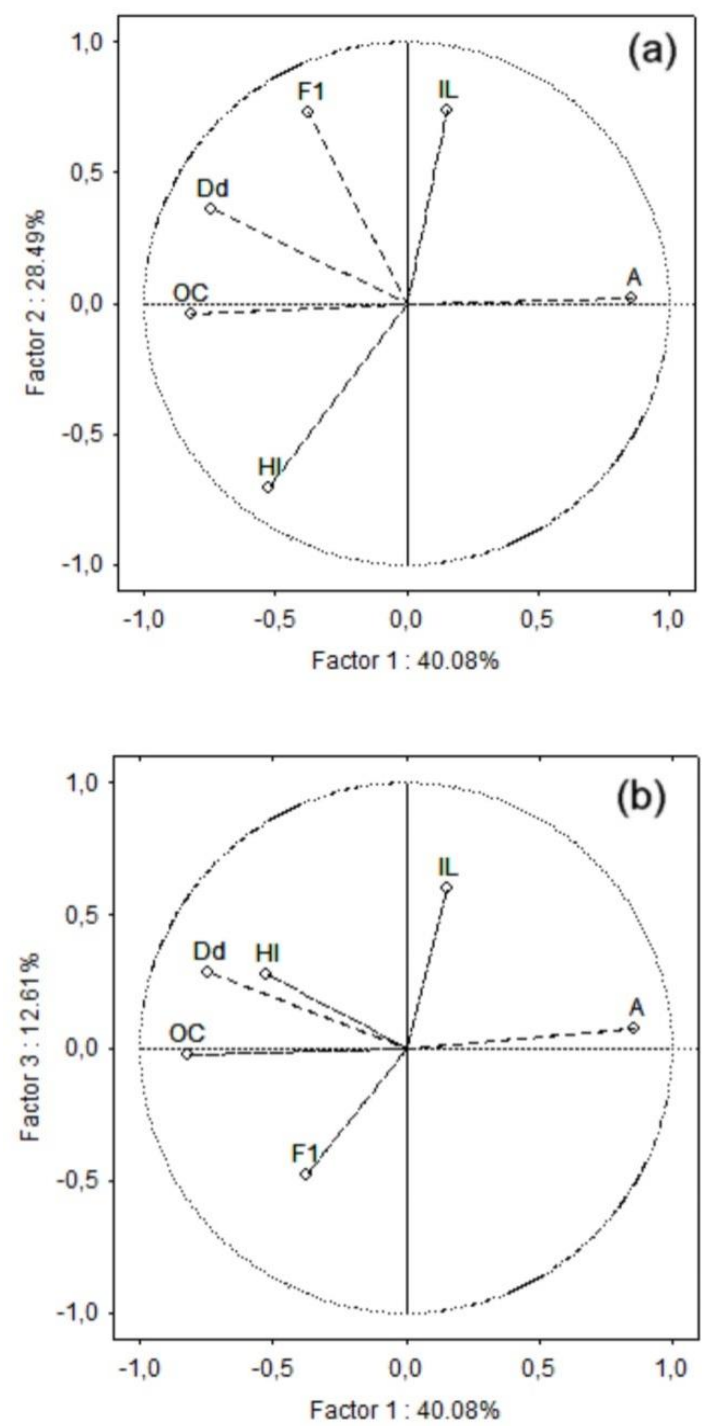

Figure 2 Projection of the variables on the factor-planes; a: $(1 \times 2), b:(1 \times 3)$
On PC1 and PC3 axes, the incision by the talwegs of the lower stream orders becomes more aggressive on the less resistant rocks. This case is particularly observed in the wadis of Cheham, El Hammam and Bouhamdane (Table 2). Conversely, a decrease in the distribution of erodible rocks will lead to a reduction of gullying, especially when the overall topography of the basin is reduced. On axis 1 , we note that the hypsometric integral is associated with the two variables of drainage density and orographic coefficient. This HI parameter shows, in fact, that it becomes more representative on the axis 1 , by still describing a high relief of the group of sub-basins that it represents.

In general, the association of the variables $\mathrm{IL}$, $\mathrm{Dd}, \mathrm{F} 1$ and $\mathrm{HI}$ is at least greatly solicited by several authors who worked on the principle of these relations in order to give explanations of the geomorphic processes and factors, hierarchy of the network and the evolution of relief (Zavoianu, 1985; Miller et al., 1990). According to Strahler, the parameters of erosion, rock resistance often show a negative relationship with the hypsometric integral during the youth stage and from the maturity stage.

On the basis of the quality of representation and contribution of each individual on the axes and in relation to circles of correlations of the variables, it is shown that the factorial projection of subbasins (PC1 and PC2) has allowed us to see the distribution of individuals (sub-basins) with the six variables. The sub-basins are subdivided into four groups (factor 1-2). On axis 1, the first group, defined by the Hammam, Rirane, M'ta Rhumel wadis, shows a high erosion and an important orography but smaller areas, lower than their mean. On the other hand, the second group, represented by Zenati, Emchekel and El Hammam wadis, has a larger area of their sub-basins and low erosion and relief (Fig. 3). These sub-basins show a dominance of erodible rocks which are mostly characterized by the mid-maturity stage to end of maturity. Sabath wadi is also distinguished by its high area but its fairly distant position on axis 1seems to be the existence of another constraint, maybe it is the dominance of the resistant rocks which has made this sub-basin located away from the group. 

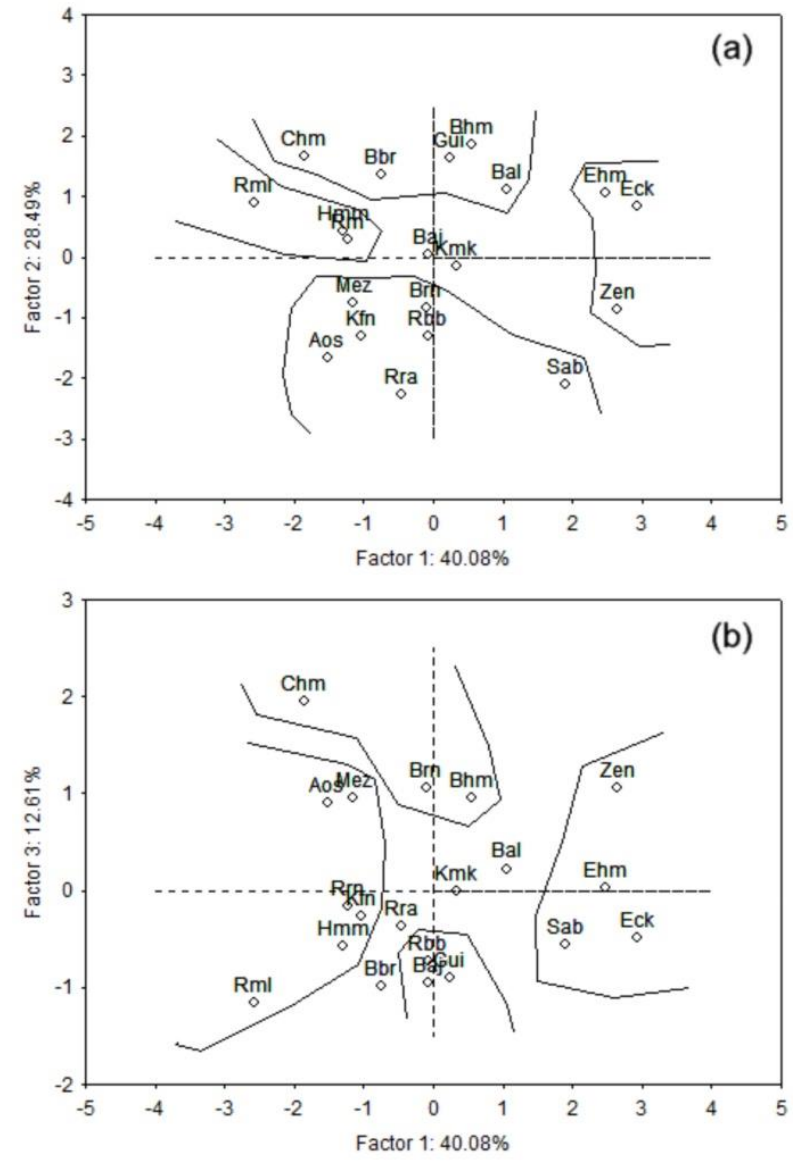

Figure 3 Projection of the subwatersheds on the factorplanes; a: (1x2), b: (1×3)

The third group, which includes the sub-basins of Guis, Bouala, Bouhamdane, Cheham and Beni Brahim wadis, is distinguished by high values of the frequency of the talwegs and the lithologic index. The quality of contribution of the Beni Brahim wadi to this relationship is rather low (33\%) because it has a smaller distribution of erodible rocks. In contrast, the fourth group composed of Meza, R'biba, Aouassia, Rararef, Sabath, Khorfane and Bouredine wadis shows rather high values of the hypsometric integral (greater than 44\%). The opposite position of the two variables (IL, F1) is mostly well represented because if the hypsometric integral is low in the sub-basins of the third group, the values of the frequency and the lithological index are generally low in the fourth group (Figure3). Moreover, the subwatersheds of the fourth group are distinguished by a substrate of more resistant outcrops and a mid-maturity stage with streams having thoroughly dissected the former highlands, and the whole area is covered with a well developed drainage network. This situation leads to the appearance of a more sparse drainage pattern than that of the third group, which is distinguished by a well-hierarchized river network developed on erodible rocks and a modest topography.

On the 1-2 axes, the same sub-basins of the first group (axis 1) plus Meza and Aouassia wadis are opposed by their erosion and topography to the second group which includes the Emchekel, El Hammam, Sabath and Zenati wadis (Fig. 3). The second group is well represented by the large areas of the sub-basins, the low values of the drainage density and generally by the modest to low topography. On axis 3, sub-basins located in the positive part of the axis are distinguished by high linear erosion due mainly to the vulnerable nature of the rocks (eg. Guis sub-basin) and, on the other hand the regional drainage pattern, geology (eg. R'biba sub-basin) will also influence the location of individual streams within a drainage basin via the action of differential erosion -i.e. as the landscape is worn down by erosion, streams will naturally tend to occupy lines of weakness caused by different rock types, faults or joints, or slight variations in rock strength. For the opposite group (group one), the intensity of the gullying depends more on the vulnerability of the clayey, marly and marly limestone lithologies.

\subsubsection{Principal component analysis of extended dataset}

In this section, the same statistical approaches are used to evaluate the major variables, principal component analysis is applied to an expanded dataset to try to explain the erosional phenomena of the sub-basins. Table 6 shows the correlation matrix derived for the expanded data set. This table is partially redundant with the initial correlation matrix of Table 3, so this discussion will focus on correlations not previously identified.

Table 6 shows that BS is negatively correlated with $A$ and positively correlated with $O C$, and to a lesser extent with F1 and HI. OFD is positively correlated with $\mathrm{HI}$ and weakly correlated with the other variables. Rh is negatively correlated with $A$ and positively correlated with $\mathrm{Dd}, \mathrm{BS}$, and strongly 
Morphometric analysis of river subwatersheds using geographic information system and principal component analysis, northeast of Algeria

positively correlated with OC. Table 7 presents the component loadings for the expanded dataset eigenvalues, the explained variability, and the based on these correlations.

Table 6 Spearman Correlation Matrix using extended dataset

\begin{tabular}{|c|c|c|c|c|c|c|c|c|c|c|}
\hline Parameters & A & Dd & F1 & HI & OC & IL & C & BS & OFD & $\mathbf{R h}$ \\
\hline A & 1.00 & & & & & & & & & \\
\hline Dd & -0.57 & 1.00 & & & & & & & & \\
\hline F1 & -0.26 & 0.38 & 1.00 & & & & & & & \\
\hline HI & -0.36 & 0.19 & -0.34 & 1.00 & & & & & & \\
\hline OC & -0.57 & 0.43 & 0.27 & 0.43 & 1.00 & & & & & \\
\hline IL & 0.17 & 0.19 & 0.22 & -0.41 & -0.10 & 1.00 & & & & \\
\hline C & -0.07 & 0.19 & -0.06 & 0.07 & 0.03 & 0.06 & 1.00 & & & \\
\hline BS & -0.56 & 0.38 & 0.41 & 0.43 & 0.51 & -0.38 & -0.06 & 1.00 & & \\
\hline OFD & -0.22 & 0.29 & -0.22 & 0.57 & 0.27 & -0.01 & -0.36 & 0.18 & 1.00 & \\
\hline $\mathbf{R h}$ & -0.69 & 0.50 & 0.36 & 0.18 & 0.84 & -0.13 & -0.04 & 0.51 & 0.17 & 1.00 \\
\hline
\end{tabular}

Table 7 Eigenvalues, Explained Variability, and principal component loadings with extended dataset

\begin{tabular}{lcccc}
\hline & Eigenvalue & $\begin{array}{c}\text { \% Total } \\
\text { variance }\end{array}$ & $\begin{array}{c}\text { Cumulative } \\
\text { Eigenvalue }\end{array}$ & $\begin{array}{c}\text { Cumulative } \\
\%\end{array}$ \\
\hline PC1 & 3.76 & 37.57 & 3.76 & 37.57 \\
PC2 & 1.91 & 19.13 & 5.67 & 56.69 \\
PC3 & 1.25 & 12.46 & 6.91 & 69.15 \\
PC4 & 1.16 & 11.6 & 8.07 & 80.75 \\
PC5 & 0.70 & 7,00 & 8.77 & 87.75 \\
PC6 & 0.48 & 4.77 & 9.25 & 92.52 \\
PC7 & 0.31 & 3.09 & 9.56 & 95.61 \\
PC8 & 0.2 & 2,00 & 9.76 & 97.61 \\
PC9 & 0.18 & 1.79 & 9.94 & 99.4 \\
PC10 & 0.06 & 0.60 & 10 & 100 \\
\hline
\end{tabular}

Correlations between variables and factors (factor loadings)

\begin{tabular}{ccccccccccc}
\hline & Factor 1 & Factor 2 & Factor 3 & Fact. 4 & Fact. 5 & Fact. 6 & Fact. 7 & Fact. 8 & Fact. 9 & Fact.10 \\
\hline A & $\mathbf{0 . 8 3}$ & -0.07 & 0.09 & -0.07 & 0,00 & -0.42 & -0.33 & -0.09 & -0.01 & -0.05 \\
Dd & -0.67 & 0.32 & 0.20 & 0.40 & 0.30 & 0.20 & -0.29 & -0.07 & -0.15 & 0.02 \\
F1 & -0.36 & $\mathbf{0 . 7 5}$ & 0.07 & -0.34 & 0.27 & -0.20 & -0.01 & 0.27 & 0.02 & -0.03 \\
HI & -0.53 & $\mathbf{- 0 . 7 2}$ & -0.09 & 0.24 & 0.13 & -0.21 & 0.12 & 0.11 & -0.19 & -0.10 \\
$\mathbf{O C}$ & $\mathbf{- 0 . 8 4}$ & 0.05 & 0.01 & 0.03 & -0.42 & -0.29 & -0.04 & 0.03 & -0.08 & 0.14 \\
IL & 0.23 & 0.55 & $\mathbf{0 . 5 7}$ & 0.43 & -0.05 & -0.18 & 0.27 & -0.12 & -0.03 & -0.03 \\
$\mathbf{C}$ & 0.00 & 0.22 & $\mathbf{- 0 . 6 4}$ & 0.70 & 0.04 & -0.12 & -0.02 & 0.05 & 0.18 & 0.00 \\
BS & $\mathbf{- 0 . 7 6}$ & -0.04 & -0.22 & -0.32 & 0.38 & -0.19 & 0.10 & -0.27 & 0.09 & 0.02 \\
OFD & -0.40 & -0.56 & $\mathbf{0 . 6 4}$ & 0.16 & 0.11 & -0.03 & -0.08 & 0.09 & 0.25 & 0.02 \\
Rh & $\mathbf{- 0 . 8 4}$ & 0.22 & 0.00 & -0.10 & -0.43 & 0.07 & -0.10 & -0.07 & 0.09 & -0.16 \\
\hline
\end{tabular}


As shown in Table 7, the first two components (PC1 and PC2) explain $37.57 \%$ and $19.13 \%$, respectively, of the total variability contained in the used variables. The third component explains $12.46 \%$ of the variation, and the remaining components explain gradually decreasing contributions (with eigenvalues $<1$ ). The first two components together account for $56.70 \%$ of the variation in the original dataset. This value is lower than the $68.57 \%$ accounted for in the PCA of the major geomorphic dataset. Addition of a third component increases the percentage of total explained variability to $69.12 \%$. The PC loadings in the lower portion of Table 7 can be interpreted as follows:

a- reflecting the contribution of the new geomorphic variables, PC1 is strongly correlated with $\mathrm{A}$, and negatively correlated with $\mathrm{OC}$ and $\mathrm{Rh}$.

b- listed in decreasing order of correlation, PC2 is most associated with $\mathrm{F} 1$ and $\mathrm{HI}$ and to lesser extent with OFD. The correlations with $\mathrm{F} 1$ and $\mathrm{HI}$ are consistent with those revealed in the initial PCA (Tables 4 and 5).

- PC3, accounting for only $12 \%$ of the variability in the data, is mainly correlated with $C$ and OFD (less strong correlations).

These associations are shown graphically in the correlation circle provided in Figure 4. Similar to the correlation circles in Figure 2, this figure graphically represents the correlations between variables and factors shown in Tables 6 and 7.

Figure 4 is interpreted as follows:

- Dd, and OC are negatively correlated with PC1 and with each other, as Rh and BS which are well represented, having BS variable slightly shorter vector length. Basin area's positive correlation on PC1 is represented as a prominent variable.

- F1 is well represented on PC2 based on the length of the vector but IL is less apparent shown by its slightly shorter vector length. The variable $C$ has a weak correlation on PC2 because of its location on the axis.

- HI is negatively well represented on PC2 with a lesser extent for OFD variable. They are both positioned at about a $45^{\circ}$ angle but with a shorter vector length for OFD (less strongly correlation).

- OFD and C are slightly well associated with PC3; they are opposing each other. These two extended variables did not account for much variation in the association.
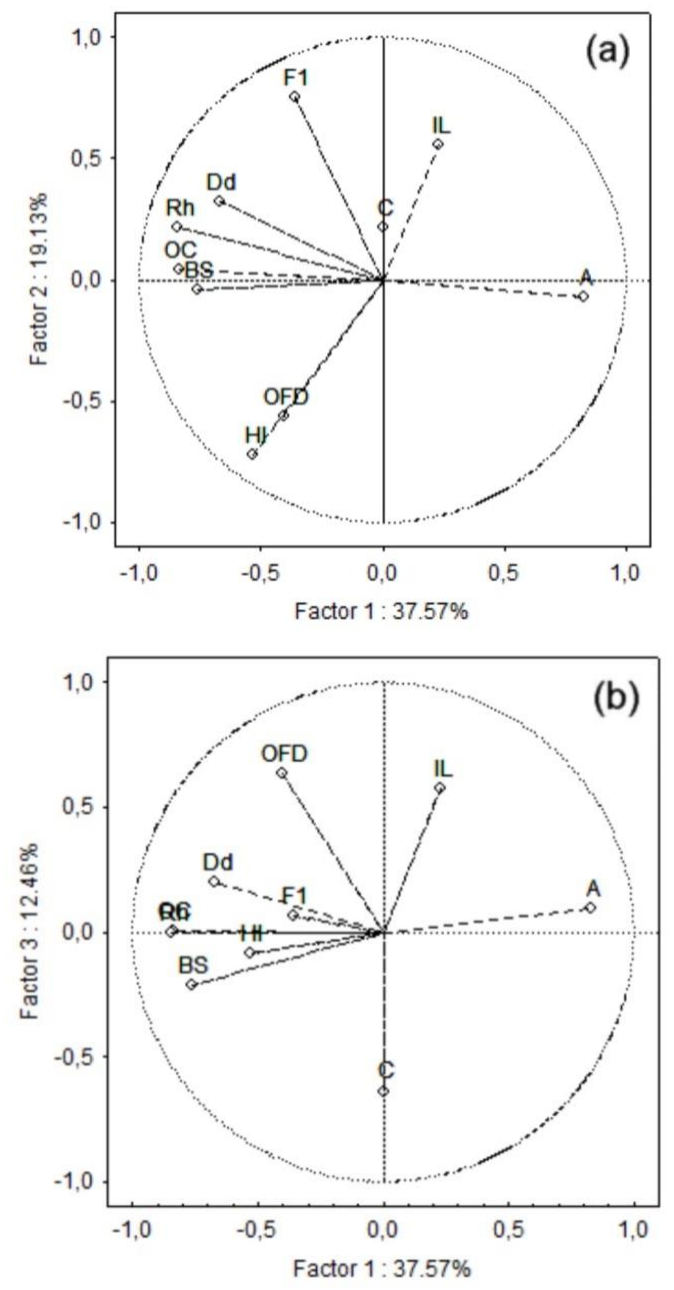

Figure 4 Projection of the variables on the factor-planes; a: $(1 \times 2), b:(1 \times 3)$

This study can be achieved by a simple comparison regarding the erosion implications using mainly drainage density (Dd), stream frequency $(F)$, relief ratio (Rh) and average basin slope (AVS) at other watersheds located in the Mediterranean region. Few studies have discussed morphometric analysis of watersheds and the available ones are from Egyptian and Lybian regions. Abdel Ghani (2015) has investigated twenty five wathersheds located between Qusseir and Abu Dabbab area at the Red Sea Coast for prioritization rating for flash flood risk estimation using morphometic parameters. Moreover, Ashmawy et al. 
(2014) have used remote sensing data, Shuttle Radar Topography Mission, coupled with geological, geomorphological data for the estimation of the flash flood risk in al-Kouf watershed, Northeast of Libya. For that, they have used morphometric analysis trying to understand the runoff potentiality in these ephemeral watersheds. Both Egyptian and Libyan regions belong to the arid-semiarid climates with intensive storm events as flood hazards. The purpose of the comparison is focusing on the drainage morphometry and its influence on erosion. The comparison between the four used morphometric parameters is being undertaken by averaging the values of each variable (Table 8).

Table 8 The calculated mean values of the morphometric parameters

\begin{tabular}{lcccc}
\hline Watersheds & Dd & F & Rh & AVS \\
\hline Algerian & 3.56 & 5.81 & 0.06 & 24.90 \\
$\begin{array}{l}\text { Qusseir-Abu } \\
\text { Dabbab }\end{array}$ & 1.86 & 1.95 & 0.03 & 43.10 \\
al-Kouf * & 1.57 & 1.71 & 0.015 & 64.84 \\
\hline
\end{tabular}

* no mean value is calculated for the watershed.

The values of the previously mentioned parameters companied with the geologic units and geomorphological features are used to discuss erosion. They are provided that the northeast Algerian subwatersheds can be classified as moderate to high runoff potentiality and the evidences of this runoff can be observed from the drainage density and stream frequency values leading to severe floor incision and fluvial deposits at basin outlets. The geological (extended erodible and fractured rocks and more impermeable subsurface soils), topographic and climatic (subhumid) conditions have favored the incision of the surface and the development of the river network. Meanwhile, the Qusseir-Abu Dabbad and al-Kouf watersheds are missing most of the later hydro-geomorphic conditions. Thus, the difference in the range of drainage density and stream frequency shown by the Qusseir-Abu Dabbad and al-Kouf watersheds may be explained by contrasts in differences of rock type and structure, evolution of landform and climate.
The Qusseir-Abu Dabbad subwatersheds are mainly composed of sedimentary rocks (sandstones, conglomerates and carbonate rocks) and granite. The area is subjected to tectonic and depositional stages which favor the existence of faults and fractures in rocks and consequently drainage channels are rapidly formed providing least resistance to erosion. The network pattern of parallel and trellis drainage confirms the steepness and strike valleys of the area. Nevertheless, these watersheds stay less eroded in comparison to the study Algerian subwaterhseds because of the hydrologic basins dissecting the mountainous area of the limited Qusseir-Abu Dabbad areal extent due to durability of basement rocks to weathering processes (Abdel Ghani, 2015).

The al-Kouf watershed exhibits contrasting landform evolution and erosional features. The effect of surface runoff in the basin is reduced because of karstification in the carbonate rocks leading to high infiltration capacity (Ashmawy, 2014). According to the author, the area is distinguished by a moderately soil erosion susceptibility and a less eroded basin because of its belonging to the youth stage where only $23 \%$ of the relief is consumed. The relative convexity shape of the hypsometric curve indicates higher relief energy (Table 8), dominated by subsurface processes.

\section{Conclusion}

The morphometric assessment has helped in the elaboration of primary hydrological diagnosis in order to predict approximate behaviour of the watershed if correctly coupled with geomorphological and geological data. Drainage density and stream frequency are both important factors that affect erosion process. Therefore, their management can cause erosion control in the regions seriously threatened. They depend on geomorphic conditions and amount of flow through the channel.

Hence, prioritization of the twenty subwatersheds is crucial, and emphasizes the need to use appropriate soil conservation measures, in order to maintain future farming sustainability. In the present study, GIS, mophometric analysis, and principal component analysis techniques have been 
employed to prioritize the subwatersheds opportunities to improve policies for their land management practices by the decision-makers.

The principal component loading matrix, using correlation matrix of six major parameters and four extended dataset, reveals that the three components together have explained $81 \%$ and $69 \%$, respectively, of the total explained variance. From the principal component analysis, factors 1-2 contribute to $69 \%$ of the total variance of six variables. The most discriminating ten variables are basin area, orographic coefficient, drainage density, stream frequency and relief ratio.

Thus, taking into account the geomorphological and geological data such as drainage density, stream frequency, topography and lithology, there are mainly Guis sub-basin, $50 \%$ of the sub-basins of

\section{References}

Abdel Ghani MK. 2015. Quantitative morphometric analysis of drainage basins between Qusseir and Dabbab area, Red Sea Coast, Egypt using GIS and remote sensing techniques. International Journal of Advanced Remote Sensing and GIS 4(1): 1295-1322.

Ashmamy M, Abd El Wahed M, Kamh S, Abdal Azim F. 2014. Drainage morphometry and its influence on runoff of El-Kouf watershed, NE, Libya, a remote sensing and GIS approach. $2^{\text {nd }}$ Scientific Conference for Environment and Sustainable Development in arid and semi-arid regions, Ajdabiya, Libya. 15p.

Bilewu SO, Sule B, Ayanshola A. 2015. Optimum parameter selection for the morphometric description of watersheds: a case study of Central Nigeria. Journal of Ecological Engineering 16(4): 29-35.

BNEDER. 1995. Etude du Bassin Versant de l'Oued Kébir Ouest (Barrage de Zit Emba). Direction Générale des Forêts, Tipaza, Algérie. Phases 1 et 2.

Castellano M, Ruiz-Filippi G, Gonzolez W, Roca E, Lema JM. 2007. Selection of variables using factorial discriminant analysis for the state identification of an anaerobic UASB-UAF hybrid pilot plant, fed with winery effluents. Water Science and Technology 51: 139-145.

Chorley RJ. 1969. Introduction to Fluvial Processes. Methuen and Co Ltd, London. 218p.

Davis WM.1899. The peneplain. American Geologist 23: 207-239.

Davis WM. 1905. The geographical cycle in an arid climate. The Journal of Geology 13 (5): 381-407. the SafSaf watershed and $100 \%$ of the sub-basins of the Mellah watershed that are affected by gullying and lateral erosion. It emerges from that, the watersheds of Mellah and Saf Saf are most affected by the erosion processes. The watershed's morphometric features determined suggest a general fragile topography which may continue to be modified by the different geomorphic processes.

The study demonstrates that the attained results have determined subwatersheds of noticeable land and water degradation, and thus of high "potential" for application of immediate conservation measures. Further studies on the subject may contribute to a better understanding of the interaction of morphometric parameters and geology in sub-basins.

Dresch J. 1950. Sur le rôle des mouvements post-pliocène et des changements de climat dans la formation du réseau hydrographique de la région de Constantine. Comptes Rendus de l'Académique des Sciences : 853855.

Duchaufour P. 1983. Pédogenèse et classification. Masson $2^{\mathrm{ème}}$ édition, Paris. $475 \mathrm{p}$.

Kouri L, H. Vogt H, GomerD. 1997. Analyse des processus d'érosion hydrique linéaire en terrain marneux, bassin de l'oued Mina, Tell oranais, Algérie. ORSTOM Bulletin Réseau Érosion 17: 64-73.

Farhan Y, Anbar A, Al-Shaikh N, Mousa R. 2017. Prioritization of semi-arid agricultural watershed using morphometric and principal component analysis, remote sensing, and GIS techniques, the Zerqa River watershed, Northern Jordan. Agricultural Sciences 8: 113- 148.

Frissel CA, Liss WJ, Warren CE, Hurley MD. 1986. A hierarchical framework for stream habitat classification-viewing streams in a watershed context. Environment Management 10: 199-214.

Gardiner V, Park CC. 1978. Drainage basin morphometry: review and assessment. Progress in Physical Geography 2(1). DOI: 10.1177/030913337800200102.

Gregory KJ, Walling DE. 1973. Drainage Basin Form and Process: a Geomorphological Approach. Edward Arnold, London. 472p.

Gregory KJ, Gardiner V. 1975. Drainage density and climate. Zeitschrift für Geomorphologie 19, 287-98.

Gottschalk L C. 1964. Reservoir sedimentation. In. VenTe Chow (ed). Handbook of Applied Geology. McGraw Hill Book Company, New York, Section 7-1. 
Gueremy P. 1977. L'évolution géomorphologique de la Calabre centrale et septentrionale. Thèse inédite. Université de Paris-Sorbonne, 6 t., 1110p.

Hack JT. 1960. Interpretation of erosional topography in humid temperate regions. American Journal of Science 258-A (Bradley Volume), 80-97.

Hajji O, Abidi S, Habaieb H, Mahjoub MR. 2015. Statistical analysis of morphometric and hydrological characteristic of small watershed in Tunisia. International Journal of Technical Research and Applications 3(1): 80-83.

Horton RE. 1945. Erosional development of streams and their drainage basins; Hydro-physical approach to quantitative morphology. Bulletinof the Geological Society of America 56: 275-370.

Hugonie G. 1979. L'évolution géomorphologique de la Sicile septentrionale. Thèse inédite; Paris IV, 949p.

Khanchoul K, Jansson MB, Lange J. 2007. Comparison of suspended sediment yield in two catchments, northeast Algeria. Zeitschrift für Geomorphologie 51(1):63-94.

Khanchoul K, Jansson MB. 2008. Sediment rating curves developed on stage and seasonal means in discharge classes for the Mellah wadi, Algeria. Geografiska Annaler 90A(3): 227-236.

Marre A. 1992.Le tell oriental algérien: de Collo à la frontière tunisienne. Etude géomorphologique. Office des Publications Universitaires, Alger. 624p.

Mather PM, Doornkamp JC. 1980, Multivariate Analysis in Geography with Particular Reference to DrainageBasin Morphometry, Transactions of the Institute of British Geographers 51 (Nov., 1970), pp. 163-187,

Melton MA. 1957.Analysis of the relations among elements of climate, surface properties and geomorphology. Project NR 389-042, Technical Report 11. Columbia University, Department of Geology, ONR, New York. 102p.

Miller JR, Ritter DF, Kochel RC. 1990. Morphometric assessment of lithologic controls on drainage basin evolution in the Crawford Upland, south - central, Indiana. American Journal of Science 290:569-599.

Mishra N, Satyanarayana T. 1988. Parameter grouping-a prelude to hydrologic modeling. Indian Journal of Power and River Valley Development 256-260, September.

Pidwirny M. 2006. The Drainage Basin Concept. Fundamentals of Physical Geography. 2nd Edition. http://www.physicalgeography.net/fundamentals/10a a.html. Accessed 5 May 2011.

Pike RJ, Wilson SE. 1971. Elevation-relief ratio, hypsometric integral, and geomorphic area-altitude analysis. Bulletin of the Geological Society of America 82: 1079-1084.
Rafael L. 1990. Hydrology: an introduction to hydrologic science. Chapter 12, 568-586. Reading, Mass., Addison-Wesley. 643p.

Ritter DF. 1984. Process geomorphology. Chapter 5, 169210. Brown Company Publishers, Iowa. 603p.

Meshram SG, Sharma SK. 2017. Prioritization of watershed through morphometric parameters: a PCA-based approach. Applied Water Science 7:1505-1519.

Scheidegger AE. 1987.Systematic geomorphology. Vienna, Springer-Verlag. 285p.

Schumm S. 1956. Evolution of drainage systems and slopes in Badlands at Perth Amboy, New Jersey. Geological Society of America Bulletin 67: 464-597.

Sharma HS.1981. Perspectives in geomorphology. NaurangRai, Concept Publishing Company, New Delhi - 110015, $109-140$.

Sharma S, Gajbhiye S, Tignath S. 2013b. Application of principal component analysis in grouping geomorphic parameters of Uttela watershed for hydrological modelling. International Journal of Remote Sensing and Geoscience 2(6):63-70.

Sharma SK, Tignath S, Gajbhiye S, Patil R. 2013a. Use of geographical information system in hypsometric analysis of KanhiyaNala watershed. International Journal of Remote Sensing and Geoscience 2(3):30-35.

Sharma SK, Gajbhiye S, Tignath S. 2014a. Application of principal component analysis in grouping geomorphic parameters of a watershed for hydrological modeling. Applied Water Science 5(1):89-96.

Singh PK, Kumar V, Purohit RC, Kothari M, Dashora PK. 2009. Application of principalcomponent analysis in grouping geomorphic parameters for hydrologic modeling. Water Resources Management 23:325-339.

Strahler AN. 1952. Hypsometric (area-attitude) analysis of erosional topography. Geological Society of America Bulletin 63: 1117-1142.

Strahler AN. 1964. Quantitative Geomorphology of Drainage Basins and ChannelNetwork. In: VenTeChow Ed. Handbook of Applied Hydrology. McGraw-Hill, NewYork, 439-476.

Saha S, Mukhopadhyay S. 2015. Determination of significant geomorphic parameters of Kunur River Basin through principal component analysis. Journal of Engineering Computers and Applied Sciences 45(8): 232-243.

Synder WM. 1962. Some possibilities for multivariate analysis in hydrologic studies. Journal of Geophysical Research 62(2):721-729.

US Department of Energy. 2012. Multivariate statistical analysis of water chemistry in evaluating the origin of 
contamination in many Devils Wash, Shiprock, New Mexico. LMS/SHP/S09257, ESL-RPT-2012-03. 61p.

Vijith H, Satheesh R. 2006. GIS based morphometric analysis of two major upland subwatersheds of Meenachil River in Kerala. Journal of Indian Society of Remote Sensing 34(2): 181-185.

Wong ST. 1979. A multivariate statistical model for predicting mean annual flood in NewEngland. Annals of the Association of American Geographers 53:293-311.

Wuttichaikitcharoen P, Babel MS. 2014. Principal component and multiple regression analyses for the estimation of suspended sediment yield in ungauged basins of northern Thailand. Water 6: 2412-2435.

Zavoianu I. 1985. Morphometry of Drainage Basins (Developments in WaterScience). 1st Edition Elsevier Amsterdam.237p. 